\title{
PENGARUH KUALITAS PRODUK DAN BRAND IMAGE TERHADAP LOYALITAS PELANGGAN ( Studi Empiris Pada Konsumen Wardah di Gerai Pusat Grosir Cililitan )
}

\author{
Tri Wijayani ${ }^{1}$, Bono Prambudi ${ }^{2 *}$ \\ 1,2 STIE Muhammadiyah Jakarta, khanzawijaya95@gmail.com, \\ bprambudi@yahoo.com (Corresponding Author)
}

\begin{abstract}
ABSTRAK
Penelitian ini bertujuan untuk mengetahui pengaruh kualitas produk, brand image secara parsial maupun simultan terhadap loyalitas pelanggan kosmetik Wardah. Data yang dikumpulkan mengunakan rumus Rao purba dengan melibatkan 100 Responden yang merupakan pelanggan produk kosmetik Wardah. Metodologi penelitian ini adalah penelitian kausal, dimana pengumpulan data dilakukan melalui kuesioner. Data yang dikumpulkan diolah dengan uji validitas, uji reabilitas, uji asumsi klasik, uji korelasi, uji regresi linear berganda, uji t, uji $\mathrm{f}$ dan koefisien determinasi Berdasarkan hasil penelitian diketahui bahwa secara persial kualitas produk $\left(\mathrm{X}_{1}\right)$ berpengaruh terhadap loyalitas pelanggan $(\mathrm{Y})$ kosmetik Wardah, brand image $\left(\mathrm{X}_{2}\right)$ tidak berpengaruh terhadap loyalitas pelanggan (Y) kosmetik Wardah. Kualitas Produk dan brand image secara simultan berpengaruh terhadap loyalitas pelanggan kosmetik Wardah. Semakin baik Kualitas Produk maka Loyalitas Pelanggan semakin meningkat dan semakin buruk Kualitas Produk maka Loyalitas Pelanggan akan menurun. Semakin baik Brand Image maka Loyalitas Pelanggan semakin meningkat dan semakin buruk Brand Image maka loyalitas pelanggan akan menurun.
\end{abstract}

Kata Kunci : kualitas produk, brand image dan loyalitas pelanggan

\begin{abstract}
This study aims to determine the effect of product quality, brand image partially or simultaneously on customer loyalty Wardah cosmetics. Data collected using the ancient Rao formula involving 100 respondents who are customers of Wardah cosmetic products. The methodology of this research is causal research, where data collection is done through a questionnaire. The data collected is processed by validity test, reliability test, classical assumption test, correlation test, multiple linear regression test, $t$ test, $f$ test and determination coefficient. Based on the research results, it is known that partially the product quality (X1) affects customer loyalty $(Y)$ Wardah cosmetics, brand image (X2) has no effect on customer loyalty (Y) of Wardah cosmetics. Product quality and brand image simultaneously affect the loyalty of Wardah cosmetics customers. The better the product quality, the higher the customer loyalty and the worse the product quality, the customer loyalty will decrease. The better the Brand Image, the higher the Customer Loyalty and the worse the Brand Image, the lower the customer loyalty.
\end{abstract}

Keywords : Quality Product, Brand Image, Custumers Loyality

Naskah diterima : 05-08-2020, Naskah dipublikasikan : 30-09-2020 


\section{PENDAHULUAN}

Perkembangan dunia kosmetik pada era globalisasi ini sangat pesat. Hal tersebut karena saat ini masalah penampilan atau kecantikan dapat dengan mudah diteratasi seiring dengan berkembangnya bermacam-macam kosmetik. Perkembangan dapat dilihat melalui produk kecantikan yang mempunyai kemampuan untuk membuat konsumen lebih puas (Gadau, 2016).

Keinginan tampil cantik dan segar adalah dambaan setiap wanita. Wanita selalu ingin terlihat cantik dan menarik setiap saat, oleh karena itu salah satu cara untuk menunjang penampilan yang menarik adalah dengan produk kecantikan. Wanita sebagai konsumen utama dalam produk kecantikan memiliki keinginan pembeli yang tinggi. Dalam menggunakan produk kecantikan biasanya konsumen selalu menggunakan produk yang sesuai dengan kulit wajahnya (Sulastri Marbun,2017).

Ada berbagai macam kosmetik merek lokal yang saat ini sedang diminati konsumen. Di Indonesia sudah mencatatkan beberapa merek lokal yaitu Sariayu, Wardah, Emina, dan Mineral Botanic. Berbagai varian kosmetik merek lokal tersebut bisa diperoleh dengan mudah dipasaran. Kosmetik yang dipasarkan menggunakan bahan-bahan yang ringan dan aman bagi kulit. Kosmetik merek lokal yang sedang populer dikalangan anak muda ini adalah Wardah, Polka Beauty, Emina, Mineral Botanica, Make over, Sariayu ( http://www.femina.co.id/beauty-trend/produk-kosmetiklokal-favorit/ pada tanggal 8 september 2016 ). Berbagai macam kosmetik merek lokal ini telah disesuaikan dengan kebutuhan kulit kaum remaja.

Hampir seluruh produk kosmetik di dunia ini mengandung campuran alkohol dimana senyawa tersebut dinyatakan dianggap haram oleh agama islam jika digunakan pada tubuh. Akibat dari kepercayaan ini wanita muslim enggan menggunakan kosmetik yang berbahan dasarnya alkohol. Untuk menyikai hal tersebut maka produsen kosemtik wardah melihat suatu peluang pasar yang menjanjikan dengan memproduksi produk kometik yang menggunakan bahan dasar tumbuhtumbuhan. Beberapa kutipan dari situs resmi kosmetik wardah (www.wardahkosmetik.com) menyatakan bahwa produk Wardah adalah produk yang pure and safe, produk tersebut mengandung bahan baku yang aman dan halal, dibuat untuk menciptakan rasa aman para penggunanya. wardah menyatukan konsep teknologi terbaru dengan mengedepankan bahan baku yang berjualitas aman serta alami. Uji pengawasan secara seksama dan terus menerus oleh tenaga ahli di bidang kosmetik dalam proses produksi. Sebelum sebuah produk Wardah di jual di pasaran maka dilakukan suatu percobaan yang dinamakan blind test yang bertujuan untuk memastikan bahwa produk yang akan dijual adalah aman. Wardah juga mengklaim bahwa perusahaannya adalah beauty expert. Dengan pengalaman yang sudah belasan tahun, Wardah dapat mengetahui karakter kulit dari wanita Indonesia dimana produk yang diproduksi selalu disesuaikan dengan kondisi wanita Indonesia. Inspiring beauty adalah suatu pernyataan yang berarti produk yang dihasilkan oleh Wardah dapat memberikan kepercayaan diri bahwa dirinya adalah cantik dan kecantikan ini berasal dari kosmetik Wardah yang digunakannya. Wardah merasa akan selalu menjadi pendamping bagi wanita Indonesia dan hal ini menjadi salah satu filosofi yang mengalir selama proses produksi Wardah kosmetik.

Karena zaman berkembang masyarakat juga semakin jeli dalam memilih, salah satunya memilih produk kecantikan. Memilih produk kecantikan tentu menjadi hal yang cukup sulit bagi sebagian perempuan, karena jika salah dalam memilih maka hasilnya tidak akan seperti yang diharapkan. Produk kosmetik menimbulkan banyak pesaing bisnis dalam industri kecantikan. Produk kosmetik dilihat dari banyaknya merek-merek yang tersebar dipasaran. Kosmetik diantaranya produk Emina, produk Sariayu, Produk Wardah dan masih banyak lainnya (Andikarini, 2017).

Produk kosmetik wardah sudah sangat terkenal dengan label halal dan atau kualitas produknya yang bagus akan tertanam dibenak konsumen dan menciptakan citra yang bagus dan positif, sehingga ketika wanita Indonesia mendengar sesuatu tentang wardah atau melihat logo itu lalu apa yang ada dalam pikiran mereka adalah bahwa wardah adalah salah satu produk kosmetik yang 
harus dimiliki oleh mereka. Indonesia memiliki penduduk yang mayoritas beragam muslim harus berhati-hati dalam memilih produk saat memilih produk kosmetik. Melihat dari kedudukan muslim yang menjadi mayoritas muslim di Indonesia, maka ini menjadi inspirasi tersendiri bagi perusahaan PT.Pragon Technology and Innovation untuk menghadirkan produk kecantikan yang bersertifikan halal pertama di Indonesia. bersertifikat halal dari LP POM MUI ( Lembaga Pengkajian Pangan, Obat dan Kosmetik Majelis Ulama Indonesia) sesuai dengan syariat Islam yang berkerjasama dengan Departemen Kesehatan (Depkes) dan Departemen Agama (Depag). Maka perempuan-perempuan Indonesia tak perlu khawatir akan dampak yang akan terjadi, karena sudah dipastikan bahwa produk tersebut aman digunakan (Farlina,2013).

Citra merek pada dasarnya merupakan hasil pandangan atau persepsi konsumen atau persepsi konsumen terhadap suatu merek tertentu, yang didasarkan atas pertimbangan dan perbandingan dengan beberapa merek lainnya, pada jenis produk yang sama. Mengembangkan citra merek yang kuat merupakan cara untuk membuat konsumen mengenal produk sehingga citra merek tersebut dapat tertanam didalam pikiran konsumen serta mampu mempengaruhi perilaku konsumen dalam menetukan pilihan. Citra merek wardah sebagai produk kecantikan harus dijaga dengan sebaik mungkin, karena perilaku konsumen sekarang ini sangat sensitiv didalam membelanjakan uangnya. Hanya produk yang berkualitas dan memiliki citra merek baik, merupakan faktor penting yang diharapkan konsumen sehingga konsumen akan puas dan tidak kecewa (Marbun, 2017)

Hasil penelitian yang dilakukan oleh Ubaidah (2016) menunjukkan bahwa loyalitas dipengaruhi oleh kualitas Produk. Sementara itu, Susanti (2015) menunjukan variabel yang berbeda yang berpengaruh terhadap loyalitas yaitu citra merek. Sedangkan Hapsari (2018) menyatakan bahwa varibel brand iamge memiliki pengaruh negatif dan tidak signifikan terhadap loyalitas pelanggan. Dari hasil tersebut menunjukkan bahwa terdapat perbedaan variabel-variabel yang signifikan mempengaruhi loyalitas pelanggan.

Dengan demikian jelaslah sudah mengapa merek kosmetik wardah merupakan salah satu merek yang disukai oleh wanita muslim terutama wanita indonesia Tulisan ini bertujuan untuk meneliti apakah sebuah kualitas produk dan brand image yang selama ini digunakan oleh Wardah mempengaruhi loyalitas para penggunanya terutama dikalangan kaum muda (milenial), termasuk mahasiswa.

\section{KAJIAN LITERATUR \\ Manajemen Pemasaran}

Pemasaran merupakan faktor penting dalam siklus yang berhubungan dengan kebutuhan konsumen. Dalam salah satu perusahaan, pemasaraan merupakan salah satu dari kegiatan pokok yang dilakukan perushaan untuk mempertahankan kelangsungan hidupnya, berkembang dan mendapatkan laba, kegiatan pemasaran perusahaan juga harus dapat memberikan kepuasan pada konsumen jika menginginkan usahanya tetap berjalan (Kurniasih, 2013)

Bedasarkan pada pendapat dapat diambil kesimpulan bahwa manajemen pemasaran adalah bentuk kegiatan pokok perusahaan yang memegang peranan penting untuk mempertahankan kelangsungan perusahaan, mengembangkan usaha untuk kemudia berubah menjadi keuntungan atau laba bagi perusahaan, pemasaran bukan hanya sekedar melakukan penjualan ke konsumen saja, namun pemasaran adalah strategi-strategi yang harus dicapai perusahaan agar mencapai tujuan yang lebih baik. 


\section{Pengertian Kualitas produk}

Kepuasan pelanggan sangat berkaitan erat dengan kualitas. Kualitas memuaskan yang sudah dirasakan konsumen memberikan kepuasan terhadap keinginan konsumen dan memenuhi kebutuhan konsumen dapat berpengaruh besar terhadap persepsi konsumen terhadap produk.

Kualitas produk menurut (Kotler, 2011:17) adalah keseluruhan ciri serta sifat dari suatu produk atau pelayanan yang berpengaruh pada kemampuannya untuk memuaskan kebutuhan yang dinyatakan atau tersirat. Amstrong (2012:27) mendefinisikan produk sebagai sesuatu yang dapat ditawarkan kedalam pasar untuk diperhatikan, dimiliki, dipakai atau dikonsumsi sehingga dapat memuaskan keinginan dan kebutuhan. Kualitas produk adalah suatu usaha untuk memenuhi atau melebihi harapan pelanggan, dimana produk tersebut memiliki kualitas yang sesuai dengan standart kualitas yang telah ditentukan oleh perusahaan, dan kualitas merupakan kondisi yang selalu berubah karena selera atau harapan konsumen pada suatu produk selalu berubah pada waktu tertentu.

Graffin Jill (2013:11) menyatakan bahwa apabila perusahaan ingin mempertahankan keunggulan kompetitifnya dalam pasar, perusahaan harus mengerti aspek dimensi apa saja yang digunakan oleh konsumen untuk membedakan produk yang dijual perusahaan dengan produk pesaing. Menurut Nurhayati (2011:25) dalam hal mutu suatu produk yang dihasilkan oleh suatu perusahaan kadang mengalami keragaman. Hal ini disebabkan mutu suatu produk itu dipengaruhi oleh beberapa faktor, manusia, manajemen, uang, bahan baku, dan mesin atau peralatan.

\section{Brand Image ( Citra Merek )}

Pengertian brand image (citra merek) sukse tidaknya bauran pemasaran tergantung dari konsumen terhadap produk yang ditawarkan oleh perusahaan. Pada umumnya proses keputusan pembelian konsumen terhadap suatu produk terjadi apabila timbul dari keinginan konsumen pada dirinya. Hal ini dapat mengalami perusahaan dengan mempertimbangkan dalam menggunakan salah sayu unsur yang terdapat dalam bauran pemasaran yaitu produk. Ada beberapa unsur penting yang terdapat dalam produk, salah satunya adalah brand image (Ende Novita Dewi, 2013:260).

Merek merupakan salah satu istilah yang dapat dipakai sebagai ringkasan dari seluruh bentuk objek pemasaran. Menutur Kotler merek adalah nama, istilah, tanda, symbol, atau desaign atau kombinasi dari semuanya itu yang dimaksudkan untuk mengidentifikasi barang atau jasa dari seorang atau sekelompok penjual untuk membedakan dari produk atau barang pesaing.

Berdasarkan deskripsi diatas maka dapat diambil kesimpulan bahwa brand image (citra merek) merupakan pemahaman konsumen mengenai merek secara keseluruhan dimana tidak semata ditentukan oleh bagaiana pemberian nama yang baik kepada sebuah produk, tetapi juga dibutuhkan bagaimana cara memperkenalkan produk tersebut agar dapat menjadi sebuah memori bagi konsumen dalam membentuk suatu persepsi akan sebuah produk.

\section{Loyalitas Pelanggan}

Loyalitas pelanggan merupakan keterkaitan emosional seorang konsuman pada sebuah merek dan berkomitmen untuk melakukan pembelian ulang (Neal, Quester, Hawkins, 2010: p.200). Loyalitas/kesetiaan pelanggan mencerminkan niatan perilaku (inended behavior) berkenan dengan suatu produk atau jasa. Niatan berperilaku di sini mecakup kemungkinan pembilan mendatang atau pembaharuan kontrak jasa atau sebaliknya, juga seberapa mungkin pelanggan akan berahli ke penyediaan layanan atau merek lainnya (Selnes,2013). Kesetiaan pelanggan dapat diukur dengan perilaku dan sikap (Getty dan Thompson, 2014). Ukuran pertama mengacu perilaku pelanggan pada pengulangan untuk memperoleh atau membeli kembali barang/jasa yang pernah dinikmati. Sedangkan ukuran sikap mengacu pada sebuah intesitas untuk memperoleh kembali dan merekomendasikan kepada orang lain.Pelanggan yang loyal atau setia adalah orang yang melakukan pembelian ualang 
perusahaan yang sama, serta memberikan informasi yang positif kepada pihak potensial lain dari mulut ke mulut (Andreanssen dan Lindestand, 2012)

Konsumen loyal melakukan pembelian terus menerus karena setia terhadap Produk yang dihasilkan oleh perusahaan tersebut selama produk yang dibeli dapat memuaskan kebutuhannya. Konsumen loyal tidak hanya puas dengan membeli suatu produk dari perushaan tersebut tetapi mereka akan berusaha untuk membeli dan mendapatkan produk-produk yang dihasilkan oleh perusahaan yang sama atau dikatakan sebagai pembeli antarlini produk. Konsumen loyal akan menceritakkan hal-hal positif mengenai produk atau jasa dari suatu perusahaan kepada rekan dan keluarganya, serta meyakinkan bahwa produk atau jasa merupakan produk yang baik sehingga ikut membeli dan menggunakan produk atau jasa dari perusahaan tersebut. Konsumen loyal menolak tawaran produk atau jasa dari pesaing karena merasa produk atau jasa yang digunakan saat ini adalah yang terbaik dan telah memberikan kepuasan. Konsumen loyal melakukan advokasi atau pembelaan ketika sesorang memberikan penilaian buruk terhadap produk tersebut.

\section{Kerangka Penelitian}

Kerangka pemikiran merupakan model konseptual tentang bagaimana teori hubungan dengan berbagai faktor yang telah diidentifikasi sebagai masalah yang penting. Kerangka berfikir yang baik akan menjelaskan secara teoritis peraturan variabel yang akan diteliti. Jadi secara teoritis perlu dijelaskan hubungan antara variabel independen dan dependen, Sugiyono (2012:60).

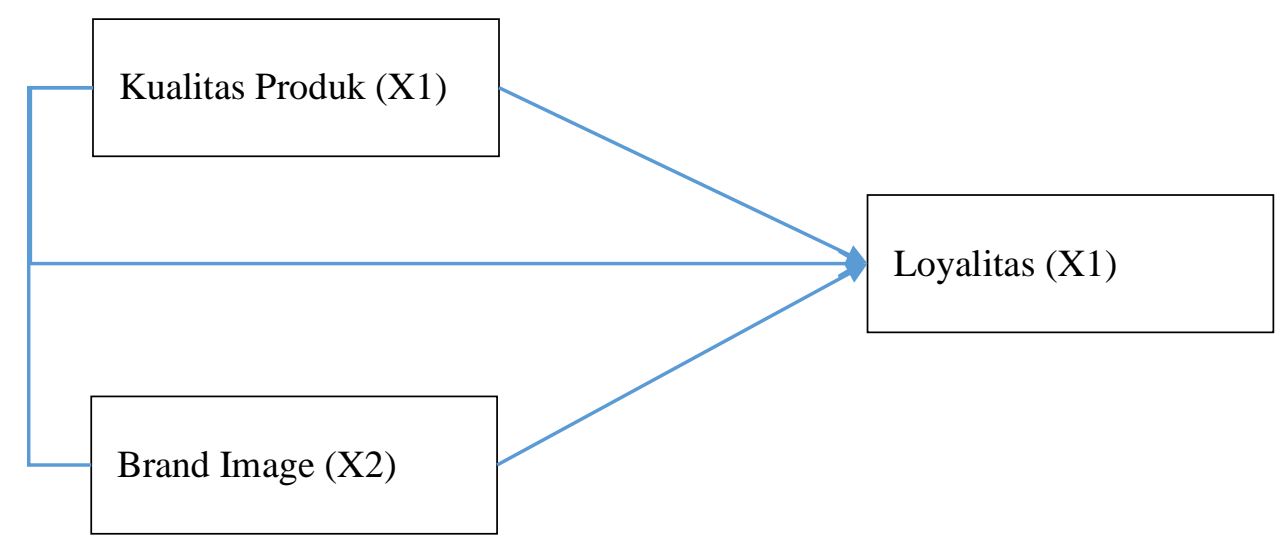

Gambar 1. Kerangka Penelitian

\section{Pengembangan Hipotesis}

Hipotesis adalah proporsi, kondisi atau pripsip yang untuk sementar waktu benar dan barangkali tanpa keyakinan, agar dapat tarik suatu konsekuensi logis dan dengan cara ini kemudia dilakukan penguji ( testing ) tentang kebenaran dengan menggunakan data empiris. Untuk dapat mengetahui pengaruh kualitas produk dan brand image terhadap loyalitas pelanggan produk wardah di Pusat Grosir Cililitan (PGC), maka dapat disimpulkan sebagai berikut (Wati,2018:63).

\section{Pengembangan Kualitas Produk terhadap Loyalitas pelanggan}

Kualitas produk merupakan faktor penentu kepuasaan konsumen setelah melakukan pembelian dan pemakian terhadap suatu produk. Kualitas produk adalah suatu bentuk dengan nilai kepuasan yang kompleks ( Hidayat,2009). Kotler dan Keller (2009:140) mengatakan bahwa konsumen yang sangat puas biasanya akan tetap setia untuk jangka waktu yang lama, serta membeli lagi ketika perusahaan memperkenalkan produk baru dan memperbaruhi produk lama, selain itu ia akan membicarakan hal-hal baik tentang perusahaan dan produk kepada orang lain, mereka tidak terlalu memperhatikan merek pesaing dan tidak terlalu mempentingkan harga, mereka juga 
menawarkan ide produk dan jasa kepada perusahaan, dan biya pelayanannya lebih murah dari pada konsumen baru karena transaksi menjadi suatu hal yang rutinm.

Hasanah (2010) menemukan bahwa adanya pengaruh Kualitas Produk dan Brand Image terhadap Loyalias konsumen. Saputro (2010) menemukan bahwa kualitas produk mempunyai nilai positif dan signifikan terhadap Loyalitas konsumen. Zainnudin (2011) menemukan adanya pengaruh yang signifikan antara Kualitas produk terhadap Loyalitas kosnumen adalah dengan adanya kepuasan dari pembelian produk yang ditawarkan kepada kosumen, mereka terus menerus membeli dan menggunakan produk itu secara berkala dan tidak tertarik dengan produk lain karena sudah percaya pada produk tersebut tetap loyalitas pada suatu produk dan merekomendasikan produk tersebut kepada orang lain.

Berdasarkan teori diatas yang dikemukakan diatas yang dilakukan oleh peneliti terdahulu, maka dirumuskan hipotesis pertama yaitu :

$H_{1}$ : Kualitas produk berpengaruh positif terhadap Loyalitas Pelanggan.

\section{Pengembangan Brand Image terhadap Loyalitas pelanggan}

Konsumen dalam memilih suatu merek produk akan memlalui tahap percobaan terlebih dahulu, pada tahap ini seringkali konsumen akan mencoba berbagai merek yang berbeda. Jika dirasakan merek tersebut cocok dan memenuhi apa yang diharapkan dari produk sejenis, maka konsumen akan terus mencari merek tersebut. Brand atau merek adalah nama, istilah, tanda, simbol desain, ataupun kombinasi yang mengidentifkasinya suatu produk atau jasa yang dihasilkan oleh suatu perusahaan. ( Darmadi Durianto, 2011:16 ).

Hubungan antara Citra Merek dengan Loyalitas Pelanggan memiliki pengaruh yang positif. Citra Merek dengan merupakan image atau sesuatu yang melekat dibenak konsumen. Semakin baik persepsi di benak konsumen yang memiliki loyalitas terhadap suatu merek maka konsumen akan melakuan pembelian ulang karena sudah percaya dan merasa puas sehingga konsumen tidak mudah tergiur dengan promisi dari pihak pesaing. Loyalitas pelanggan merupakan efek akhir dari suatu pembelian, yang diartikan sebagai suatu dan niat untuk berprilaku di masa depan, dan di saulurkan melalui hal-hal seperti komitmen untuk membeli kepada perusahaan jika membutuhkan produknya, komitmen untuk memberikan rekomendasi kepada orang lain dengan menceritakan hal yang positif tentang perusahaan dan kesediaan untuk membayar mahal. Namun terdapat hasil yang berbeda oleh Nurul Vivit Hapsari (2018) yang berjudul "Pengaruh Lebel Halal,Citra Merek dan Kualitas Produk terhadap Loyalitas pelanggan Dengan kepuasan Konsumen Sebagai Variabel Intervening" yang menyatakan brand image berpengaruh negatif terhadap loyalitas pelanggan.

Berdasarkan teori diatas yang dikemukakan diatas yang dilakukan oleh peneliti terdahulu, maka dirumuskan hipotesis kedua yaitu :

$\mathrm{H}_{2}$ : Brand Image tidak berpengaruh positif terhadap Loyalitas Pelanggan.

\section{METODE PENELITIAN}

Penelitian ini merupakan penelitian kasual yaitu penelitian yang mencari hubungan (pengaruh) sebab akibat yaitu variabel independen atau bebas (Pengaruh Kualitas Produk dan Brand Image Terhadap Loyalitas Pelanggan ) terhadap variabel terikat atau dependen (Loyalitas Pelanggan). Variabel-variabel yang akan diteliti dalam penelitian ini adalah sebagai berikut, Kualitas Produk $\left(\mathrm{X}_{1}\right)$, Brand Image $\left(\mathrm{X}_{2}\right)$, dan Loyalitas Pelanggan $(\mathrm{Y})$.

Populasi yang digunakan dalam penelitian ini adalah pelanggan wardah di Pusat Grosir Cililitan (PGC) Jln. Dewi Sartika RT.001/RW.013, Kelurahan Cililitan, Kecamatan Kramat Jati, Kota Jakarta Timur, Daerah Ibukota Jakarta Mall Bassura. Populasi dalam penelitian ini belum diketahui secara pasti jumlahnya, maka penentuan sampelnya bersifat non probability sampling. Berdasarkan 
hal tersebut maka teknik sampelnya adalah sampling insidential, artinya responden yang dipilih adalah mereka yang datang ke grosir tersebut pada saat ambil sampel. Melihat keragaman pelanggan yang relatif homogen maka sampel untuk sebanyak 100 Responden sudah cukup mewakili.

\section{HASIL DAN PEMBAHASAN \\ Statistik Deskriptif}

Tabel 1. menunjukkan bahwa responden cenderung menyatakan baik terhadap kualitas produk wardah. Begitu juga terhadap brand wardah, bahwa wardah memiliki brand image yang baik. Berkaitan dengan loyalitas, konsumen wardah juga menunjukkan loyalitas yang baik. Namun, penilaian loyalitas dibandingkan dengan dua variabel sebelumnya relatif sedikit lebih lemah.

Tabel 1. Tabel Distribusi Data

\begin{tabular}{|c|c|c|c|c|c|c|c|c|c|c|c|}
\hline \multirow{2}{*}{$\begin{array}{l}\text { Variabel } \\
\text { Penelitian }\end{array}$} & \multicolumn{2}{|c|}{$\begin{array}{c}\text { STS } \\
1\end{array}$} & \multicolumn{2}{|c|}{$\begin{array}{c}\text { TS } \\
2\end{array}$} & \multicolumn{2}{|c|}{$\begin{array}{c}\mathbf{R R} \\
\mathbf{3} \\
\end{array}$} & \multicolumn{2}{|c|}{$\begin{array}{l}S \\
4\end{array}$} & \multicolumn{2}{|c|}{$\begin{array}{c}\text { SS } \\
5\end{array}$} & \multirow[t]{2}{*}{ Mean } \\
\hline & $\mathbf{F}$ & $\%$ & $\mathbf{F}$ & $\%$ & $\mathbf{F}$ & $\%$ & $\mathbf{F}$ & $\%$ & $\mathbf{F}$ & $\%$ & \\
\hline \multicolumn{11}{|c|}{ KUALITAS PRODUK } & 4,314 \\
\hline$X_{1.1}$ & 0 & 0 & 0 & 0 & 0 & 0 & 17 & 16,8 & 83 & 82,2 & $\mathbf{4 , 8 3}$ \\
\hline$X_{1} .2$ & $\mathbf{0}$ & $\mathbf{0}$ & $\mathbf{0}$ & $\mathbf{0}$ & 4 & 4,0 & 48 & 47,5 & 48 & 47,5 & $\mathbf{4 , 4 4}$ \\
\hline $\mathbf{X}_{1.3}$ & $\mathbf{0}$ & $\mathbf{0}$ & $\mathbf{0}$ & $\mathbf{0}$ & 16 & 15,8 & 45 & 53,5 & 30 & 29,7 & 4,14 \\
\hline$X_{1.4}$ & 0 & 0 & 0 & 0 & 3 & $\mathbf{3 , 0}$ & 63 & 62,2 & 34 & 33,7 & $\mathbf{4 , 3 1}$ \\
\hline$X_{1.5}$ & 0 & 0 & 2 & 2,0 & 28 & 27,7 & 53 & 52,5 & 17 & 16,8 & $\mathbf{3 , 8 5}$ \\
\hline \multicolumn{11}{|c|}{ BRAND IMAGE } & 4,524 \\
\hline $\mathbf{X}_{2.1}$ & $\mathbf{0}$ & $\mathbf{0}$ & $\mathbf{0}$ & $\mathbf{0}$ & 2 & 2,0 & 30 & 29,7 & 68 & 67,3 & 4,66 \\
\hline$X_{2.2}$ & $\mathbf{0}$ & $\mathbf{0}$ & 1 & $\mathbf{1 , 0}$ & 4 & 4,0 & 48 & 47,5 & 47 & 46,5 & $\mathbf{4 , 4 1}$ \\
\hline $\mathbf{X}_{2.3}$ & $\mathbf{0}$ & $\mathbf{0}$ & 2 & 2,0 & 4 & 4,0 & 52 & $\mathbf{5 1 , 5}$ & 42 & 41,6 & 4,34 \\
\hline $\mathbf{X}_{2.4}$ & $\mathbf{0}$ & $\mathbf{0}$ & $\mathbf{0}$ & $\mathbf{0}$ & 3 & $3, \mathbf{0}$ & 34 & 33,7 & 63 & 62,4 & 4,60 \\
\hline$X_{2.5}$ & $\mathbf{0}$ & $\mathbf{0}$ & 1 & 1,0 & 1 & 1,0 & 34 & 33,7 & 64 & 63,4 & 4,61 \\
\hline \multicolumn{11}{|c|}{ LOYALITAS PELANGGAN } & 3,696 \\
\hline$Y_{1.1}$ & 0 & 0 & 1 & 1,0 & 30 & 29,7 & 41 & 40,6 & 28 & 27,7 & 3,96 \\
\hline$Y_{1.2}$ & 0 & $\mathbf{0}$ & 1 & $\mathbf{1 , 0}$ & 4 & 4,0 & 55 & 54,5 & 40 & 39,6 & $\mathbf{4 , 3 4}$ \\
\hline $\mathbf{Y}_{1.3}$ & 1 & 1,0 & 8 & 7,9 & 68 & 67,3 & 20 & 19,8 & 3 & 3,0 & 3,16 \\
\hline$Y_{1.4}$ & $\mathbf{0}$ & $\mathbf{0}$ & 12 & 11,9 & 44 & 43,6 & 32 & 37,7 & 12 & 11,9 & 3,44 \\
\hline$Y_{1.5}$ & $\mathbf{0}$ & $\mathbf{0}$ & 9 & 8,9 & 38 & 37,5 & 39 & 38,6 & 14 & 13,9 & $\mathbf{3 , 5 8}$ \\
\hline
\end{tabular}

Uji Validitas dan Uji Realiabilitas

\section{Uji Validitas}

Uji validitas dari 100 responden, jika nilai uji > 0,361 dinyatakan valid. Dari hasil pengolahan data pra-kuisioner pada 100 responden, diperoleh hasil data sebagai berikut :

Tabel 2. Hasil Uji Validitas Varibabel Kualitas Produk

\begin{tabular}{|c|l|c|c|c|}
\hline No & \multicolumn{1}{|c|}{ Indokator } & R hitung & R tabel & Keterangan \\
\hline 1 & $\begin{array}{l}\text { Produk meng gunakan bahan bahan yang halal dan } \\
\text { aman digunakan }\end{array}$ & 0,371 & 0,361 & Valid \\
\hline 2 & Produk sangat m udah saat diaplikasikan di kulit & 0,627 & 0,361 & Valid \\
\hline 3 & $\begin{array}{l}\text { Produk tidak ada efek samping dalam } \\
\text { penggunaan }\end{array}$ & 0,514 & 0,361 & Valid \\
\hline 4 & $\begin{array}{l}\text { Produk tidak ada efek samping dalam } \\
\text { penggunaan }\end{array}$ & 0,535 & 0,361 & Valid \\
\hline 5 & $\begin{array}{l}\text { Produk mempunyai bahan ya ng tahan lama pada } \\
\text { saat digunakan }\end{array}$ & 0,440 & 0,361 & Valid \\
\hline
\end{tabular}

Sumber : data diolah,2019 


\section{JURNAL EKOBIS: EKONOMI, BISNIS \& MANAJEMEN \\ Vol 10 Nomor 1 (2020)}

Berdasarkan Tabel 2. mengenai hasil uji validitas untuk variabel kualitas produk, didapat kan bahwa semua $r$ hitung lebih besar daripada $r$ tabel yaitu 0.361, maka tolak Ho karena $r$ hitung $>r$ tabel, artinya dapat disimpulkan bahwa instrument-instru men pernyataan dalam variabel kualitas produk valid dan dapat d igunakan dalam penelitian ini.

Tabel 3. Hasil Uji Validitas Varibabel Brand Image

\begin{tabular}{|c|l|c|c|c|}
\hline No & \multicolumn{1}{|c|}{ Indokator } & $\mathrm{R}$ hitung & $\mathrm{R}$ tabel & Keterangan \\
\hline 1 & $\begin{array}{l}\text { Merek kosmetik wardah memiliki ciri khas } \\
\text { kehalalan }\end{array}$ & 0,221 & 0,361 & Tidak Valid \\
\hline 2 & Merek Wardah memiliki banyak varian & 0,607 & 0,361 & Valid \\
\hline 3 & Merek Wardah selalu mengutamakan kualitas. & 0,533 & 0,361 & Valid \\
\hline 4 & Merek Wardah sudah dikenal banyak orang & 0,516 & 0,361 & Valid \\
\hline 5 & Merek wardah mudah diucapkan dan diingat & 0,523 & 0,361 & Valid \\
\hline
\end{tabular}

Sumber : data diolah,2019

Berdasarkan Tabel 3. mengenai hasil uji validitas untuk variabel brand image, didapatkan bahwa semua $r$ hitung lebih besar daripada $r$ tabel yaitu 0.361, maka tolak Ho karena $r$ hitung $>r$ tabel, artinya dapat disimpulkan bahwa instrument-instrumen pernyataan dalam variabel harga valid dan dapat digunakan dalam penelitian ini.

Tabel 4. Hasil Uji Validitas Varibabel Loyalitas Pelanggan

\begin{tabular}{|c|l|c|c|c|}
\hline No & \multicolumn{1}{|c|}{ Indokator } & R hitung & $\mathrm{R}$ tabel & Keterangan \\
\hline 1 & Kesediaan untuk tetep memakai produk wardah & 0,429 & 0,361 & Valid \\
\hline 2 & $\begin{array}{l}\text { Bersedia menyebarkan informasi positif kepada } \\
\text { orang lain }\end{array}$ & 0,366 & 0,361 & Valid \\
\hline 3 & Bersedia untuk tidak menggunakan produk lain & 0,504 & 0,361 & Valid \\
\hline 4 & $\begin{array}{l}\text { Merasa puas dengan hasil pemakaian dalam } \\
\text { waktu seminggu }\end{array}$ & 0,578 & 0,361 & Valid \\
\hline 5 & $\begin{array}{l}\text { Akan tetap menggunakan wardah karena } \\
\text { merasa cocok dan puas }\end{array}$ & 0,582 & 0,361 & Valid \\
\hline
\end{tabular}

Sumber : data diolah,2019

Berdasarkan Tabel 4. mengenai hasil uji validitas untuk variabel loyalitas pelanggan, didapatkan bahwa semua $r$ hitung lebih besar daripada $r$ tabel yaitu 0.361, maka tolak Ho karena $r$ hitung > $\mathrm{r}$ tabel, artinya dapat disimpulkan bahwa instrumen-instrumen pernyataan dalam variabel loyalitas pelanggan valid dan dapat digunakan dalam penelitian ini.

\section{Uji Reliabilitas}

Suatu variabel dikatakan reliabel jika memenuhi nilai dari Cronbach Alpha > 0,6. Uji reliabilitas dilakukan dengan melakukan penyebaran kuisioner pada 100 responden yang hasilnya adalah :

Tabel 5. Hasil Uji Reliabilitas Variabel kualitas produk

\begin{tabular}{|c|c|}
\hline Cronbach's Alpha & Keterangan \\
\hline 0,725 & Reliabel \\
\hline
\end{tabular}

Sumber : data diolah,2019

Berdasarkan Tabel 5. hasil uji reliabilitas untuk variabel Promosi yaitu sebesar 0,725, lebih besar dari nilai Cronbach's Alpha yaitu 0,60 yang berarti variabel kualitas produk reliabel dan dapat dapat digunakan dalam penelitian ini 


\section{Uji Reliabilitas Variabel brand image}

Tabel 6. Hasil Uji Reliabilitas Variabel brand image

\begin{tabular}{|c|c|}
\hline Cronbach's Alpha & Keterangan \\
\hline 0.719 & Reliabel \\
\hline
\end{tabular}

Sumber : data diolah, 2019

Berdasarkan Tabel. 6 menunjukkan bahwa hasil uji reliabilitas untuk variabel harga yaitu sebesar 0,719, lebih dari nilai Cronbach's Alpha yaitu 0,60 yang berarti variabel harga reliabel dapat digunakan dalam penelitian ini.

\section{Uji Reliabilitas Variabel loyalitas pelanggan}

Tabel 7. Hasil Uji Reliabilitas Variabel loyalitas pelanggan

\begin{tabular}{|c|c|}
\hline Cronbach's Alpha & Keterangan \\
\hline 0,728 & Reliabel \\
\hline
\end{tabular}

Sumber : data diolah,2019

Berdasarkan Tabel 7. menunjukkan bahwa hasil uji reliabilitas untuk variabel Loyalitas Pelanggan yaitu sebesar 0,728, lebih besar dari nilai Cronbach's Alpha yaitu 0,60 yang berarti variabel Brand Image reliabel dan dapat digunakan dalam penelitian ini.

\section{Uji Asumsi klasik}

Uji Normalitas

Uji normallitas dalam penelitian ini dilakukan dengan uji statistik non-parametrik Kolmogorov-Smirnov (K-S). Kriteria suatu data residual berdistribusi normal yaitu nilai Asymp. Sig. (2-tailed) $>0,05$. Uji normalitas dalam penelitian ini dapat dilihat pada Tabel 9 :

Tabel 8. Hasil Uji Normalitas dengan Uji Kolmogorov-Smirnov

\begin{tabular}{|c|c|c|}
\hline Nilai & Asymp. Sig. (2-tailed) & Keterangan \\
\hline 15,978 & 0,200 & Data terdistribusi normal \\
\hline
\end{tabular}

Sumber : data olah,2019

Penelitian ini disesuaikan dengan uji hipotesis sebagai berikut:

Ho : Data berdistribusi normal

$\mathrm{Ha}$ : Data berdistribusi tidak normal

Jika Sig. > 0,190 maka Ho diterima. Jika Sig. < 0,05 maka Ho ditolak.

Berdasarkan hasil uji normalitas pada tabel 8. dapat diketahui bahwa hasil uji normalitas yaitu sebesar 0.200 harus dibagi dua terlebih dahulu karena penelitian ini merupakan penelitian 1-tailed, menjadi 0,10>0,05 maka Ho diterima, yang berarti data berdistribusi secara normal.

\section{Uji Heteroskedastitas}

Dilihat dari gambar pada hasil output SPSS dibawah, terlihat varians dari residu tersebut tidak mempunyai pola tertetu atau tersebar secara acak, sehingga regresi tidak mengandung unsur heterokedastisitas. 


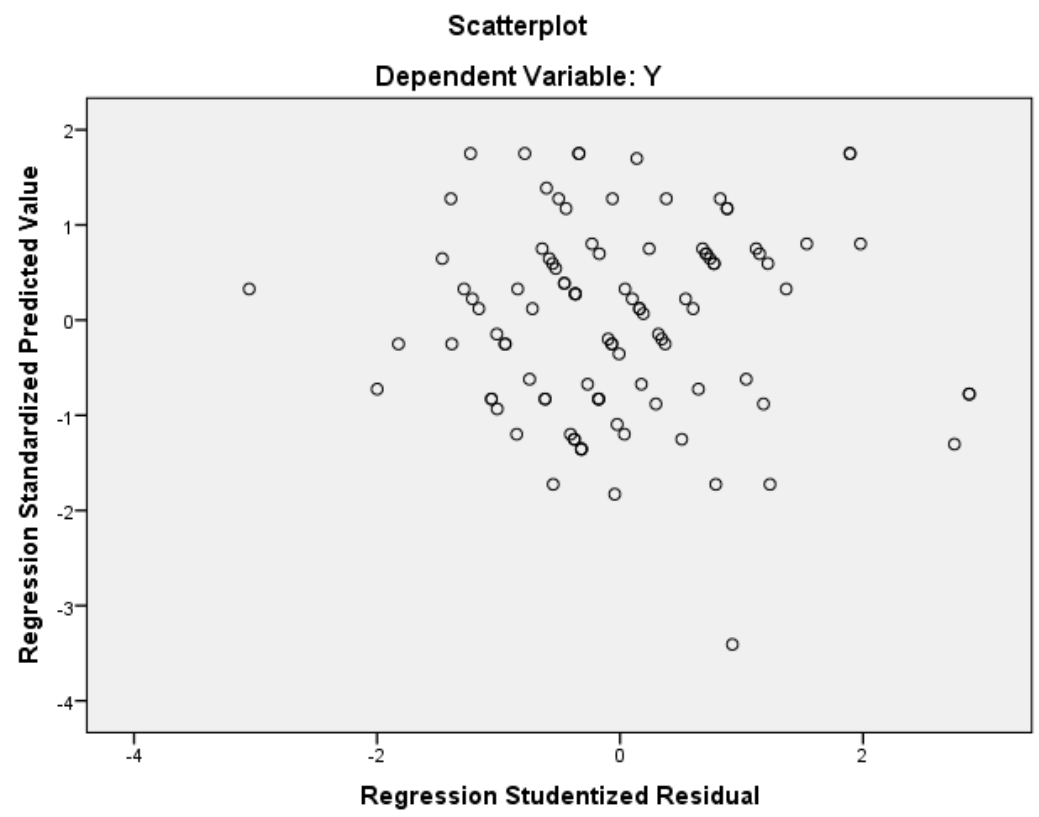

Gambar 2. Scatterplot Uji Heteroskedastitas Loyalitas Pelanggan Sumber : Hasil Output SPSS 22

Dari output pada Gambar 2. diketahui bahwa titik-titik menyebar di atas dan di bawah angka 0 pada sumbu Y. Jadi secara visual tidak terjadi heteroskedastisitas pada model regresi.

\section{Uji Multikolinearitas}

Uji multikolonieritas di dalam model regresi dapat dilihat dari nilai tolerance dan nilai Variance Inflation Factor (VIF). Model regresi yang bebas multikolonieritas adalah yang mempunyai nilai VIF $<10$ dan nilai tolerance $>0,1$. Untuk mengetahui lebih lanjut mengenai multikolinearitas dapat dilihat pada Tabel 9:

Tabel 9. Hasil Uji Multikolinearitas

\begin{tabular}{|c|c|c|c|}
\hline Variabel & Tolerance & VIF & Keterangan \\
\hline Kualitas produk & 0,860 & 1,163 & Tidak tedapat multikolinearitas \\
\hline Brand image & 0,860 & 1,163 & Tidak terdapat multikolinearitas \\
\hline
\end{tabular}

Sumber : data diolah,2019

Ho : Tidak terdapat multikolinearitas

Ha : Terdapat multikolinearitas

Jika VIF $<10$ dan atau Tolerance $>0,01$ maka Ho diterima.

Jika VIF $>10$ dan atau Tolerance $<0,01$ maka Ho ditolak.

Dari tabel di atas dapat dijelaskan bahwa nilai VIF sebesar $1,163<10$ dan nilai Tolerance sebesar $0,860>0,01$ maka Ho diterima. Berarti dalam model penelitian ini tidak terdapat multikolinearitas. Model regresi yang baik adalah tidak terdapat multikolinearitas atau tidak terjadi korelasi antar variabel independen. Model regresi dalam penelitian ini baik dan dapat di olah untuk penelitian selanjutnya. 


\section{Analisis Regresi Berganda}

Uji Keberartian Model (Uji F)

Uji F menunjukan hasil dalam tabel 10. secara bersama-sama berpengaruh secara signifikan terhadap (Y).

Tabel 10. Hasil Uji Keberartian Model (Uji F)

\begin{tabular}{|c|c|c|}
\hline F & Sig. & Keterangan \\
\hline 15,978 & 0,000 & Model fit dan layak digunakan dalam penelitian \\
\hline
\end{tabular}

Sumber : data diolah, 2019

Berdasarkan Tabel 10. diketahui bahwa nilai F hitung 15,978 dengan nilai Sig. sebesar 0,000 $<0,05$. Jadi dapat disimpulkan bahwa variabel bebas (kualitas produk,brand image) secara simultan mampu menjelaskan perubahan pada variabel tergantung (loyalitas pelanggan) dinyatakan model regresi fit dan layak digunakan sehingga dapat dilanjutkan untuk pengujian.

\section{Uji Signifikan Koefisien (Uji t)}

Uji t menunjukkan bahwa pengaruh secara parsial anatara variabel independen (Promosi, Harga, Kualitas produk, Brand Image) terhadap variabel dependen (Keputusan Pembelian).

Persamaan Regresi Estimasi yang digunakan adalah:

$$
\begin{aligned}
& \text { Keterangan : } \\
& Y=0,727+0,617\left(X_{1}\right)+0,067\left(X_{2}\right)+e \\
& \mathrm{Y}=\text { Loyalitas Pelanggan } \\
& \mathrm{X} 1=\text { Kualitas produk } \\
& \mathrm{X} 2=\text { Brand Image }
\end{aligned}
$$

Tabel 11. Hasil Uji Signifikan Koefisien (Uji t)

\begin{tabular}{|c|c|c|c|}
\hline Variabel & $\begin{array}{c}\text { Koefisien } \\
\text { Regresi }\end{array}$ & $\begin{array}{c}\text { Koefisien Regresi } \\
\text { Terstandarisasi (Beta) }\end{array}$ & Sig. \\
\hline Kalitas Produk & 0,617 & 0,476 & 0,000 \\
\hline Brand Image & 0,067 & 0,052 & 0,587 \\
\hline
\end{tabular}

Sumber : data diolah, 2019

Berdasarkan Tabel 11. nilai Sig untuk kualitas produk sebesar $0,000<0,05$. Berarti kualitas produk memiliki pengaruh positif terhadap loyalitas pelanggan. Lalu, nilai Sig untuk brand image sebesar 0,587 >0,05. Berarti brand image tidak berpengaruh secara signifikan terhadap loyalitas pelanggan, Adapun juga nilai Koefisien Regresi Terstandarisasi (Beta) terbesar dimiliki oleh variabel kualitas produk yaitu sebesar 0,476 , hal ini menunjukkan bahwa variabel kualitas produk memiliki pengaruh paling besar terhadap loyalitas pelanggan.

\section{Koefisien Determinasi}

Tabel 12. Hasil Uji Koefisien Determinasi

\begin{tabular}{|c|c|c|}
\hline R & R Square & Adjusted R Square \\
\hline 0,498 & 0.248 & 0.232 \\
\hline
\end{tabular}

Sumber : data diolah,2019 
Nilai Adjusted R Square menjelaskan besaran persen variabel dependen (loyalitas pelanggan) diterangkan oleh variabel independen (kualitas produk, brand iamge), dengan nilai sebesar 0,232 atau 23,2\% yang berarti variasi nilai Loyalitas Pelanggan tercerminkan oleh variasi nilai Kualitas Produk dan Brand Image sebesar $23,2 \%$, sisanya yaitu $76,8 \%$ dipengaruhi oleh variabel lain yang tidak diteliti.

\section{PEMBAHASAN}

Berdasarkan analisis penelitian yang telah dilakukan dengan menggnakan kuesioner yang dikembangkan dari indikator pada variabel penelitian. Dimana kulitas produk terdapat pengaruh loyalitas pelanggan yang cukup baik, maka akan dibahas hasil temuan sebagai berikut.

\section{Pengaruh Kualitas Produk Terhadap Loyalitas Pelanggan Kosmetik Wardah}

Seperti pada hipotesis di atas, hasil penelitian ini juga menunjukkan bahwa ada pengaruh positif dan Signifikan antara kualitas produk terhadap loyalitas pelanggan. Hal ini dibuktikan dengan hasi uji statistik uji t Untuk kualitas produk sebesar $0,000<0,05$. Berarti kualitas produk memiliki pengaruh positif dan signifikan. Hasil penelitian ini mendukung penelitian sebelumnya dilakukan oleh Ubaidah (2016) berjudul "Pengaruh Citra Merek, Kualitas Produk Wardah Terhadap Kepuasan dan Loyalitas Pelanggan" menyimpulkan bahwa Kualitas Produk memiliki pengaruh positif dan signifikan terhadap Loyalitas Pelanggan.

\section{Pengaruh Brang Image Terhadap Loyalitas Pelanggan Kosmetik Wardah}

Hasil penelitian menunjukkan bahwa ada pengaruh negatif dan tidak Signifikan antara brand image terhadap loyalitas pelanggan. Hal ini dibuktikan dengan hasi uji statistik uji t Untuk brand image sebesar $0,000<0,05$. Berarti brand image memiliki pengaruh negatif dan tidak signifikan koefisien regresi mepunyai nilai negatif sebesar 0,052 maka penelitian ini berhasil membuktikan hipotesis yang menyatakan bahwa "Variabel Brand Image $\left(\mathrm{X}_{2}\right)$ Tidak berpengaruh positif terhadap Loyalitas Pelanggan (Y). Hasil penelitian ini mendukung penelitian sebelumnya dilakukan oleh Hapsari (2018) yang berjudul "Pengaruh Lebel Halal, Citra Merek dan Kualitas Produk terhadap Loyalitas pelanggan Dengan kepuasan Konsumen Sebagai Variabel Intervening" menyimpulkan bahwa varibel brand iamge memiliki pengaruh negatif dan tidak signifikan terhadap loyalitas pelanggan. Loyalitas pelanggan terhadap produk wardah karena wardah merupakan sedikit produk kosmetik nasional atau satu-satunya yang menggunakan pendekatan syariah yang kuat, sehingga loyalitasnya tidak terkait kuat dengan brand produk tersebut.

\section{PENUTUP \\ Simpulan}

Kualitas produk berpengaruh positif dan signifikan terhadap loyalitas pelanggan. Produk wardah pada konsumen Pusta Grosir Cililitan (PGC) Jakarta Timur. Brand Image (Citra Merek) tidak berpengaruh positif dan signifikan terhadap loyalitas pelanggan. Produk Konsumen Pusat Grosir Cililitan (PGC) Jakarta Timur.

\section{Saran}

Dalam penelitian ini kualitas produk berpengaruh secara signifikan terhadap loyalitas pelanggan produk Wardah. Maka diharapkan Wardah bisa mempertahankan serta meningkatkan kualitas produknya agar pelanggan semakin loyal dalam membeli produk Wardah dan meningkatkan keuntungan perusahaan. brand image (citra merek) tidak berpengaruh dan signifikan terhadap loyalitas pelanggan produk Wardah. Maka diharapkan wardah mampu memperbaiki dan meningkatkan citra dan merek perusahaa sehingga dapat meningkatkan loyalitas pelanggan. 


\section{REFERENSI}

Destalianiko Andikarini,(2017) Pengaruh Kualitas Produk,Citra Merek.dan Harga Pada Keputusan Pembelian Untuk Lipstik Wardah Berdasarkan Karakteristik Demografis di Yogyakarta

Wati, L.N. 2017, Metodologi Penelitian Terapan, Aplikasi SPSS

Fandy, Tjiptono (2011). Pemasaran jasa. Malang: Malang

Febrianto, Lucky,. 2011, Analisis Pengaruh Kualitas Jasa Terhadap Loyalitas Pelanggan Bus Damri Kota Semarang, Universitas Diponegoro Semarang.

Griffin, Jill. 2013. Menumbuhkan dan Mempertahankan Kesetian Pelanggan. Jakarta: Erlangga.

Getty , J.M \& Thompson, N.K, 2014, The relationship between quality, satisfaction, and recommending behavior in lodging decisions. Journal of hospitality and leisure Marketing.

Ika Pratiwi, D, dan Sugiarto, S., 2010, Analisis Pengaruh Harapan Pelanggan, Kulitas Produk, Kepuasan Pelanggan Terhadap Loyalitas Pelanggan Internet Flash Unlimited Di Semarang (Doctoral dissertation,Univetsitas Diponegoro).

Kotler, Philip. 2009. Manajemen Pemasaran. Jakarta : Erlangga.

Kotler, Philip. 2011. Manajemen Pemasaran dan Analisis Perencanaan, Implementasi dalam Perencanaan, Jillid 11. Jakarta: Erlangga.

Kotler, Phillip dan Gary Amstrong. 2015. Dasar dasar Pemasaran. Jillid 2. Jakarta: PT. Indeks Kelompok Geramedia.

Kotler,Phillip \& Killer (2009). Manajemen pemasaran. Terjemahaan Bob Sabar. Edisi ke 13 Jilid 1. Jakarta : Erlangga

Mochamad Rizki, (2016). Pengaruh Iklan dan Citra Merek Terhadap Loyalitas Pelanggan Produk Kometik Wardah.

Nurul Vivit Hapsari (2018) . Pengaruh Lebel Halal,Citra Merek dan Kualitas Produk terhadap Loyalitas pelanggan Dengan kepuasan Konsumen Sebagai Variabel Intervening.

Salnes, F., 2013, An examination of the effect of product performence on brand reputation, satisfaction and loyalty. European journal of marketing 27(9), 19-35

Sinanga, Pratua Pramana Hamonangan, 2010, "Analisis Pengaruh Kualitas Pelayanan, Kepuasan Pelanggan, dan Lokasi Terhadap Loyalitas Pelanggan ( Studi Kasus Pada Warnet Chamber Semarang )", Universitas Diponegoro Semarang.

Siti Ubaidah, 2016, Analisis Pengaruh Citra Merek, Kualitas produk Wardah Terhadap Kepuasan dan loyailitas Pelanggan dikota jember

Sugiyono. 2009. Metode Penelitian Bisnis (Pendekatan Kantitatif, Kalitatif dan H\&R). Bandung: CV. Alfabeta Bandung

Tio Fanta Sulastri Marbun (2017). Pengaruh Kualitas Produk dan Citra Merek Terhadap Keputusan Pembelian Produk Kosmetik Wardah Di Cikarang Utara

http://blog:pricepedia.org/id/brand-kecantikan-kosmetik-lokalberkualitas/

https://www.paragon-innovation.com

https://youtu.be/isrx9q7s-M

https://youtu.be, up6487BzlpA

https://yout.be/UJh8boc_z4c

https://yout.be/gZ0ObUyuDqo

www.wardahkosmetik.com 